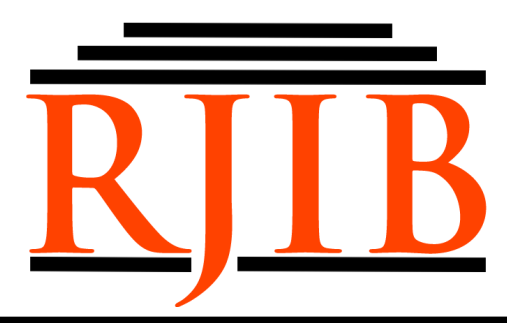

RETORIKA: Jurnal Ilmu Bahasa

Vol. 5, No. 2 Oktober 2019, Page 148-158

P-ISSN: 2406-9019

E-ISSN: 2443-0668

Available Online at https://ejournal.warmadewa.ac.id/index.php/jret

\title{
Code Switching in English Language Learning at Pabelan Islamic Boarding School
}

\author{
Cintia Yudita \\ Yogyakarta State University, Indonesia \\ cyudita@gmail.com
}

\begin{tabular}{|l|}
\hline Received: $16 / 07 / 2019 \quad$ Revised: 26/09/2019 Published: 15/10/2019 \\
\hline How to cite (in APA style): \\
Yudita. C. (2019). Code Switching in English Language Learning at Pabelan Islamic Boarding School. RETORIKA: \\
Jurnal Ilmu Bahasa, 5(2), 148-158. doi: http://dx.doi.org/10.22225/jr.5.2.1204.148-158 \\
\hline
\end{tabular}

\begin{abstract}
This research aims to describe the use of code switching in English language learning, in terms of the form of code switching, the kind of code switching, the aim of code switching, the function of code switching and the causal factors of code switching. This study belongs to qualitative research. The subjects of this research were the English teacher and students. Meanwhile, the data were utterances of English teacher and students that contained code switching. The data were collected through observation, recording, note-taking and interview. Classroom activities, particularly in the teaching of English language, were recorded on video tapes and field notes. The data analysis revealed several findings. First, both teacher and students used word form of code switching, phrase form of code switching and sentence form of code switching when they were in the classroom. Second, the English teacher and the student used intern and extern code switching, temporary code switching, situational and metaphorical code switching. Third, the aim of using code switching done by the teacher and students were compensating for language limitation, to explain the material and strategy in teaching learning process. Fourth, the functions of code switching for teachers and student were as clarification, emphasis, repetition, translation, checking for understanding, tool for communication, developing vocabulary and tolerance. Fifth, the factors that caused code switching were to fulfil a need, to express or declare solidarity, to respect the listener and to be more informative.
\end{abstract}

Keywords: code switching, English language learning

\section{INTRODUCTION}

Language has become an important part of our life. In our social environment, people use it to communicate with others. There are some definitions about language. (Hornby, 1995) defines language as a system of sounds, words, pattern, etc. He also defines language as the system of communication in speech and writing used by people of a particular country. It carries the purpose or the idea of the language itself. Meanwhile, (Wardaugh, 2006) state that language is arbitrary symbol and system used by human to communicate. According to (Alwasilah, 1985) Communication is a process by which information is exchanged between individuals through a common system of symbols, signs, or behaviors. People often use a spoken language, written language or even body language to convey a message or their thought. The people who are involved in a communication may master some languages. In spite of speakers' languages mastery or languages acquisition, in a communication the speakers might switch two or more languages by inserting other elements of the languages. Those people who speak or master two languages are called bilingual, whereas the people who speak more than two languages are called multilingual. Bilingual and multilingual are possible to switch the codes or the languages while they communicate.

$$
\text { (Nababan, 1984) state that code }
$$


switching is the changing of using the language or language variety to another depending on situation. Furthermore, (Wardaugh, 2006) state Code switching is a process to decide to switch from one code to another or to mix codes even within sometimes very short utterances and thereby create a new code. The forms of code switching divided into three parts are code switching in word form, phrase form and in the sentence form. Moreover, the kind of code switching can be divided into some classification. The classifications are based on the origin of language, the characteristic of momentum and status relationship between speakers and contextual classification. Based on the origin of language classification, (Chaer \& Agustina, 2010) divides two kinds of code switching, intern code switching and outer code switching. Then, based on the characteristic of momentum and status relationship between speakers classification (Poedjosoedarmo, 1978) divided code switching into two, namely temporary code switching and permanent code switching. The last classification is based on the contextual classification (Wardaugh, 2006) divided code switching into two, namely situational code switching and metaphorical code switching. Then, about the aim of code switching, have found that the teacher can use code switching as a scaffold when communicating in the target language, where it is used to maximize understanding as it is can be used to support the comprehension of the language to keep the conversation ongoing. (Oxford, 1990) states that L1 will be a strategy to overcoming limitations in speaking and writing lesson. Furthermore, (Cook, 1991) states that some of the ways that teachers have found the first language useful in the classroom are to explaining the grammar to the students, explaining tasks and exercises to the students and students using the first language within classroom activities. Meanwhile, about the function of code switching, (Fachriah, n.d.) on her research found that the functions of code switching in English language classroom for teacher are: (1) clarification, (2) reiteration or repetition, (3) explanation, (4) asking, (5) translation, (6) checking for understanding, (7) emphasizing a language element, (8) making inferences, (9) developing vocabulary, (10) class discussions of student tasks, (11) giving feedback, (12) aiding memorization, (13) class management and (14) entertainment and general communications. In communication code switching has function as to emphasize an important notion, to substitute the unfamiliar word in second language, to explain notion having no cultural identity with other language, to release tension and create humor, to introduce new topic. It is accordance to enumerated in her paper some feasible situations for code switching. Given are the few conditions; Lack of one word in either language, some ideas are expressed easily in native language, for clarification of misinterpretation, to develop influence of communication for effective purpose, and one wishes to express group solidarity. The last about the causal factors of code switching, (Wardaugh, 2006) states that solidarity, accommodation to listeners, choice of topic, and perceived social and cultural distance brings a speaker to choose variety $\mathrm{X}$ of a language $\mathrm{A}$ rather than variety $\mathrm{Y}$, or even language $A$ rather than language $B$. In accordance to (Chaer \& Agustina, 2010) states that speaker, listener, the presence of third person, the changing of language varieties and the changing of topic are the causal factors code switching occurs.

A number of researchers, (Ahmad, 2009) (Dente et al., 2016) (Obaidullah, 2016) (Jingxia, 2010) have argued that code switching is a good strategy to be used in EFL classroom. It facilitates teaching learning process and provides a better understanding of the lesson content. Others, (Modupeola, 2013) code switching is important for teaching language at the foundation level to attract the interest of the learners but must be gradually reduced as the learner progresses in proficiency level. The findings of the research showed that code switching has pedagogic function such as explaining new words and grammatical rules, giving feedback, checking comprehension, making comparison between English and Vietnamese, establishing good rapport between teachers and students, creating a friendly classroom atmosphere and supporting group dynamics.

This study adopted a similar stance on the issue, particularly, when a classroom of multilingual learners has switched the language into their mother tongue (Bahasa). Since the English language is the second language, the English teacher and students faced several difficulties. Their difficulties are it is difficult for the English teacher to implement all the stages of teaching learning process using English language only, it is difficult for the students to understand and to continue learning process when the teacher only speaks in English language, the students tend to have low enthusiasm in English language learning 
process when the teacher only speaks in English language, the students lack of vocabulary when they are speaking, the students are reluctant to discover meaning and synonym of some words in the dictionary, the English teacher and students have difficulties to find out the equivalent word in English language, the students cannot retrieve some word in English language from their brain and the last is the students have a problem in making sentence using English language only. Since Bahasa understood by the students, the English teacher uses it to make teaching learning process more transferrable and acceptable for her students.

The objectives of this study based on the formulation of the problems are:

1. To find out the forms of code switching that used in teaching and learning activity in the classroom at Pabelan Islamic Boarding School.

2. To find out the kinds of code switching that used in teaching and learning activity in the classroom at Pabelan Islamic Boarding School.

3. To find out the aims of code switching that used in teaching and learning activity in the classroom at Pabelan Islamic Boarding School.

4. To find out the functions of code switching that used in teaching and learning activity in the classroom at Pabelan Islamic Boarding School.

5. To find out the factors that cause code switching happens in teaching and learning activity in the classroom at Pabelan Islamic Boarding School.

\section{METHOD}

This research was conducted in Pabelan Islamic Booarding School. The type of this research is qualitative research. This research is a descriptive analytical view of bilingualism especially about code switching on speaking skill in English language subject. The English teacher and the students at $\mathrm{X}$ grade of Pabelan Islamic boarding school involved as subject. Meanwhile, the data of this research is the utterances of English language teacher and student contained of code switching. To gather the data, there are four techniques used by the researcher. The techniques are observation, record, note-taking and interview (Moleong, 2007). Then, Research instrument divided into three parts human instrument, interview guidelines and the parameter of code switching.
The next phase of this research is to analyze the data. To analyze the data, the researcher used metode padan (comparing method). According to (Sudaryanto, 1993) comparing method divided into two teknik dasar and teknik lanjutan. The last, to obtain the validity of the data, the researcher used triangulation of method and triangulation of source.

\section{RESULT AND DISCUSSION}

\section{The forms and the kinds of code switching}

Overall, there were 267 utterances of English teacher and students that contained code switching. The forms of code switching divided into word form, phrase form and sentence form of code switching. Meanwhile, the kind of code switching divided into three classification. The first is the origin of language classification it divided into the intern and extern code switching. Then, code switching based on the characteristic of momentum and status relationship between speakers classification divided into two, temporary and permanent code switching. The last is code switching from contextual classification, situational and metaphorical code switching.

\section{Word form of code switching}

In this research, the researcher found 99 words that classified as the form of code switching. To decided the words are code switching or not, the researcher analyzed during the conversation occurs is there contains some purposes, the function and there also the reason of code switching. The data of word form of code switching showed below.

Teacher: Iqbal, I don't like to see you put your head on the table.

Student: Yes miss.

Teacher: Do you know nyepeti?

The italic word is the form of code switching in word. In data (1) the sentence "Do you know nyepeti?" called as code switching, because the teacher speaks from English language into Javanese language within a single utterance. From the teacher' utterance "Do you know nyepeti?" we can conclude that the teacher added word "nyepeti" on her sentence has function as a tool for communication. Based on the origin of language, conversation (1) is included in extern code switching.

\section{Phrase form of code switching}

There are 75 phrases that indicate as 
code switching. Here is the data of code switching in phrase form.

Teacher: Sympathy in English. Our care and our attention.

: Are you ok? What happened with you?

: Tapi ada yang sangat popular in English.

Student : What's wrong? Aya nawon?

The data (2) code switching showed in phrase aya nawon. Since the second speaker used two languages, English and Sundanese language it called the extern code switching.

\section{Sentence form of code switching}

The researcher finds out 93 sentences as code switching. Here are the data of code witching in the sentence level.

Teacher: Ok good. So sympathy not only in bad situation,

but also in good situation. The example of sympathy

in good situation are wow wonderful, I'm happy to hear that and nice. Any question?

Student: No.

Teacher: Ok there is no question and I think that's all.

Please study and good luck. I really trust you, jadi saya percaya kalian.

Based on the data above code switching can be seen easily. Every sentence shows that they have the autonomy on their own language. From data (3), Code switching was start from word jadi to kalian.

\section{The intern code switching}

The intern code switching is switching the speaker's first language with their regional language as long as it is still in one national language. The intern code switching used fewer than the extern code switching only 19 intern code switching were found. By the recording data, the teacher and student switch Bahasa and Javanese language, or Javanese language with Sundanese language. Here is the data about intern code switching.

Teacher: Do you bring your dictionary? Student : No.

Teacher: So open your mind. Do you know shiny?

Student: Kempling. Silau.

Based on the data (4) the students and the teacher used Bahasa and Javanese language. It classify as the intern code switching because Bahasa and Javanese language is in one national language. The intern code switching contained in sentence "Kempling, Silau". Kempling is the Javanese language and in English language it has meaning "shiny". Then, the student translates it into Bahasa.

\section{The extern code switching}

Meanwhile, for the extern code switching, the teacher and students switch between their mother tongue and foreign language. For example, they switch Bahasa with English language or even with Arabic language. Based on the data, 248 extern code switching were found in the word form, the phrase form and the sentence form. Here is the data of extern code switching.

Teacher: Finish?

Student: Not yet miss.

Teacher: Yo ayo kumpulkan. Qod jaros.

The data (5) showed that there are two languages used in one utterance, the English language and the Arabic language. It indicates that data (5) is extern code switching. At the first utterance, the teacher used English language then, on her next utterance, the sentence "Yo ayo kumpulkan. Qod jaros" used Bahasa and Arabic language. Qod jaros is the Arabic language, in English language it means "the bell was ringing".

\section{Temporary code switching}

Temporary code switching occurs for a while, and then the speaker will switch the code to the first language they used before. All of the utterances that contains code switching were temporary code switching, the result show that 267 code switching are temporary code switching. Here is the data form temporary code switching.

Teacher: Siapa to yang kanis hari ini?

Every Tuesday your class so dirty.

Student: Bersih bu biasane.

Teacher: No, every Tuesday your class so dirty.

The data (6) at the first sentence was used two languages, Bahasa and Arabic language. "Kanis" is the Arabic language, it means picket. The teacher used those languages temporarily. It can be seen from the next sentence, she used English language. Based on the characteristic of momentum and status relationship between speakers, the teacher used code switching and it was temporary code 
switching. At first utterance she used between Bahasa and Arabic language, then in the next utterance she switches into English language.

\section{Permanent code switching}

Permanent code switching does not found in the teacher and students' utterances. The teacher states that she cannot use one language permanently. In her explanation the teacher said that she cannot use Bahasa only because their target language is English language. Meanwhile, she also cannot use English language in whole teaching learning process. She argued that sometimes she needs to switch the code into Bahasa, it adjust to the need. For example, when there are difficult words and it may not be understood by the students, then she will use Bahasa as translation.

\section{Situational Code Switching}

Situational code switching occurs when participants redefine each other's right and obligations. It also happens based on the situation where the speaker realizes that they speak in some language in some situation and other language in other situation. There is no topic change in situational code switching. The result show that 265 utterances that contains code switching are situational code switching. Here is the data from situational code switching.

Teacher: The most effective advertisement.

$$
\text { Yo wes gek jawab wae! }
$$

Is there any truth of advertisement?

Student: Truth, kebenaran.

$$
\begin{aligned}
& \text { Advertising makes people happy } \\
& \text { first. }
\end{aligned}
$$

Teacher: Oke, is there any truth about advertising?

Student: so many miss

From the data (7) the teacher switches the code into Javanese language. At first utterance she speaks in English language, and then she switches into Javanese language. She speaks in Javanese as her command to the students to answer immediately. It is the extern code switching. There was no topic change in the data (7). The teacher and student change the language only to adjust with the situation.

\section{Metaphorical Code Switching}

Metaphorical code switching is occurs when a change of topic requires a change in the language used. Metaphorical code switching changed the code as redefine the situation formal to informal, official to personal, serious to humorous, and politeness to solidarity. The result shows that only 2 utterances that contains code switching are metaphorical code switching.

Teacher: Some student in front of the door.

Do you want to join with my class?

Student: No miss.

Teacher: Ok greet them girls.

Student: Halo.

Teacher: Ok silent.

\section{Keliatan to orang yang dari papua tu ga pernah lihat orang, suaranya seru sendiri.}

Ok stop, we are going to study about something new.

What you don't like when watch television?

What don't you like not what do you like?

The data (8) is the metaphorical code switching, in the last utterance the teacher changes the language into Bahasa as the situation also change from serious situation into humorous situation. She asks her student to greet some student outside the class. When her student greets the student outside the class, there was one student who shouted very loudly. She is comes from Papua. So the teacher said "Keliatan to orang yang dari papua tu ga pernah lihat orang, suaranya seru sendiri." then other student laughed at their friend. In conclusion, the teacher talks such as sentence solely for joke. It was proven when they were laughed together after the teacher said that.

The table of forms and the kinds of code switching were found from the English teacher and students' utterance presented in the appendices.

\section{The Aims, the Functions and the reasons of Code Switching}

The aim of code switching, the English teacher and students are confirmed that was used widely to perform these aims. 114 the utterances of English teacher and students that contained code switching was used to compensating for language limitation. 69 the utterances of English teacher and students that contained code switching were used when the teacher explain the material. 84 the utterances of English teacher and students that contained code switching indicates as strategy in teaching learning process. 
Besides that, code switching has functions as clarification about student understanding, to emphasize the important notion, to repeat the difficult word, to translate the material, checking for understanding, as a tool for communication, developing vocabulary, and tolerance. There were 5 code switching used by the English teacher as clarification about student understanding. 61code switching to emphasize the important notion, 14 to repeat the difficult word, 40 code switching used to translate the material, 10 for checking for understanding, 97 as a tool for communication, 27 for developing vocabulary and the last is there were 13 code switching used by the teacher and students as their tolerance.

In addition, 172 the utterances of English teacher and students that contained code switching indicates to fulfill a need. Also, 8 code switching confirmed used to express or decelerate solidarity. Then, 13 code switching used when the English and students show that they respect the listener. The last, 74 code switching used when the English teacher and students give the information or in other word they want be more informative for others.

\section{The Aims of Code Switching}

Based on the data found the aim of code switching for the teacher and the student at Pabelan Boarding School divided into three parts. Namely: compensating for language limitation, to explain the material, and as strategy in teaching learning process.

\section{Compensating for language limitation}

Code switching helped to overcome the language limitation. Here is the data that show how compensate the language limitation in the classrooms.

Teacher: Distinguish means? Different?

What different means?

Distinguish and different has the same meaning, berbeda.

Teacher: Difference?

Student: Perbedaan.

Teacher: Our difference is? I'm white and you are black.

Student: Haha thank you miss.

Meanwhile, on data (9) the teacher ask the meaning of distinguish, because there is no answer from the students then she gives the synonym. Different was the synonym of distinguish, but there still no answer. In the end, to compensating the student' language limitation the teacher translate it into Bahasa.

\section{To explain the material}

During English language teaching learning, the teacher used code switching to explain the material. The teacher state is not easy to explain the material only in a language. Although it is difficult, at the beginning of the explanation the teacher uses English language only. But if student seem do not understand the teacher switch into Bahasa. Here is the data that show how code switching will explain the material.

Teacher: Here are the materials for oral examination

Student: Introduction and text miss?

Teacher: Yes. The material includes the introduction, text and then the expression.

Introduced yourself and one member of your family. Jadi besok itu perkenalan,

perkenalkan diri kalian dan salah satu anggota keluarga kalian. Gitu ya?

\section{Paham?}

Based on the data (10) the teacher switches the code from English language into Bahasa to explain about the material of the oral examination. Properly, during teaching learning process it is best to explain in the language target and avoid switching the code into mother tongue. In fact, she cannot do that, because her duty is to deliver the material and the student understands about it.

\section{Strategy in teaching learning process}

Code switching used as strategy in teaching learning process. Strategy is a tool to facilitate teaching learning process, in which it used to reach the aim of teaching learning process. When the teacher did not found the appropriate word in English language she switches the code into Bahasa. It was solely to maintain the continuity of communication between teacher and students. Here is the data that show how code switching will be strategy in teaching learning process.

Teacher: Have you known the story before?

Pernah dengar sebelumnya?

Student: Pernah.

Teacher: Dimas do you know the story about golden egg?

Student: No. 
Teacher: Ok I will read the story. Golden, do you know the meaning of golden? Open your ears. One day, once upon a time, long time ago.

From the data (11) the teacher switches the code in her explanation, because she finds it as the strategy to deliver her material to students. It is also the strategy to keep the continuity of discussion.

\section{The function of code switching}

Then, the result about the function of code switching for the teacher in teaching learning process are to clarification, emphasis, repetition, explanation, translation, checking for understanding, tool for communication, developing vocabulary and tolerance.

\section{Clarification}

Clarification conducted by the teacher and the student to clarification or confirmation about the explanation, question and statement. In order to avoided misunderstanding in capture the message. Here are the data that contained of clarification.

Teacher: Selanjutnya ekspresi apa itu?

Student: Complaint.

Teacher: No. it's disappointed.

$$
\text { Saya puas. Apa saya puas? }
$$

Student: I'm satisfied.

Teacher: Kalau saya kecewa? I'm disappointed. Jangan ganggu saya? Don't disturb me.

The data (12) the teacher' utterance "No. it's disappointed. Saya puas. Apa saya puas?" used to confirmation about her explanation. The teacher used it to make sure about the students' understanding.

\section{Emphasize}

The use of code switching has a function to emphasize. Relate to teaching learning process, after long explanation the teacher usually emphasized her student through code switching to make sure about the students' understanding. The data of code switching has the function of emphasize as below:

Teacher: Ok good we are going to study about iklan. Advertisement.

What advertisement do you like on tv?

Student: Sunlight, susu, food, drink, miss milk miss.

Teacher: Now I explain about advertisement.
I would like to ask you to discuss about what topic in this paper.

Don't worry this is simple question. Oke please take one.

From the data (13) showed that the teacher try to emphasize the important notion by using English language word "Advertisement". Through that word, she tries to emphasize about the material that they will discuss.

\section{Repetition}

The teacher needs to repeat her explanation in bahasa to make sure her student get the point of her explanation. Repetition used to explain or to ask the difficult word only. The data below showed how repetition carries out the duty as function of code switching.

Teacher: My best friend got passed away.

Passed away tu meninggal.

Oke kemudian syifa bilang apa ketika mendengar itu?

Student: I'm symphaty with you.

Teacher: Ok oke this is the most popular expression to express Our sympathy in bad situation. I'm sorry to hear that.

Form the data (14) the teacher said "Passed away tu meninggal." She knows that "passed away" is the difficult or new words for her students. In her opinion she needs to repeat it in Bahasa, the she said "meninggal" as her repetition.

\section{Translation}

For the teacher, translation is an effective way to transfer the material. Based on the result of recording there was many times both teacher and student interpreted or translate the material into their first language. Here is the data of translation that occurs during teaching learning process.

Teacher: Greedy, serakah.

Do you know shiny?

Student: Kempling. Silau.

Teacher: Mengkilat.

In data (15) the teacher mentioned "Greedy, serakah." it was translation form. The teacher translates word "greedy" into Bahasa it was solely to explain about the material. In this data by translate the word into Bahasa, the teacher also tries being more informative to her student.

Checking for understanding 
Checking for understanding is one of the most important things to conduct by the teacher in classroom. It functions was to measure about the success of teaching learning process. By asking the student about the explanation before, then ask them to give some conclusion or sometimes only ask about the difficult word only are the ways to checking the students' understand. The data of code switching as function for understanding mentioned below.

Teacher: And then making appointment.

\section{Membuat apa? Membuat perjanjian.}

\section{Student: Apa lagi bu?}

Teacher: kemudian ada juga ekspresi happiness dan sedih sad yang akan saya terangkan hari ini.

Based on the data (16) the teacher mentions the meaning of the word that she was mention before. The teacher use code switching to ask the students about the material that was explained before. It has function for check the student understanding.

\section{Tool for communication}

Code switching as a tool for communication, as the social bilingual, it is normal to used code switching in a conversation. Code switching has the effect for continuity of the conversation. When the teacher does not know about a word, or she was forget. She can switch it into Bahasa, and then the communication between the teacher and student will be continued. That is how code switching performs its role as a tool in communication. Here is the data that contains of code switching as tool for communication.

Teacher: Hoirudin what's wrong with u today,

\section{kamu biasanya diligent.}

I don't like to see you put your head on the table.

Kalau bahasa jawanya nyepeti.

Student: Apa artinya bu?

Teacher: Ayo don't put your head on the table

On data (17) the code switching which can be identified is on the sentence "kamu biasanya diligent". As a bilingual even multilingual speaker, the code switching usually appears in a communication. The teacher said "kamu biasanya diligent" solely as a tool to keep continuity of communication.

\section{Developing vocabulary}

The aim of translation, the explanation and repetition that was conducted by the teacher is for developing her students' vocabulary. The teacher was ready to translate the difficult word or to interpret the word that students never knew before. That was her way to help the student add their vocabulary. The data about developing vocabulary occurs can be seen below.

Teacher: What the matter with you azizah?

Student: I hurt my leg

Teacher: For your information, ketika kalian sakit kalian jangan

bilang my foot is sick, tapi I hurt my foot. Then what would azizah say?

Student: Get well soon.

Based on data (18) in the italic word the teacher gives further information about how to express when the student is sick or ill. She explains about the expression in English language. The more she explains about the material, the more new word those students will get. It means her students' vocabulary increased.

\section{Tolerance}

Related with the teaching learning process, when the English teacher delivers the material she must pay attention to her students. She does not allowed to continue the process of teaching learning when the student only gawk at her. When the teacher or student used those languages (English language and Bahasa) in one utterance, it is also the form of their tolerance. The data of code switching as tolerance is below.

Teacher: No asking, no discussing. Who have finish?

Student: Not yet miss, belum miss.

Based on the data (19) the student switches the code to make sure her friends understand what she was said. The sentence "Not yet miss, belum miss" was indicate that student tolerance with her friends. Her reason because she respect her friends as the listener, that may do not understand the meaning of " $n o t$ yet".

\section{The causal factors of code switching}

The last about the factors that caused code switching occurs are to fulfill a need, to express or declare solidarity, respect the listener, and being more informative.

\section{To fulfill a need}

The teacher or the student, who may not be able to express him or herself in one language, might switch it to another language to compensate for the deficiency. Code 
switching occurs might be because both teacher and student upset, tired or distracted in some manner, or the less fluent in one language. The data can be seen below.

Teacher: Ok. The next grup.

Student: Winner kami miss. Why you choose the product?

Before I use product I will see the price.

Teacher: Price. Oke good.

Data (20) the word "kami" used to fulfill a need. Those words "Winner kami miss" indicates that the speaker also less fluent in English language so she uses Bahasa. It used to compensate the language limitation and it also has function as a tool for communication.

\section{To express or to declare solidarity}

Code switching commonly occurs when an individual wishes to express solidarity with a particular social group. Sometimes, the teacher or student switch from one language to another accidently, but in many situations, code switching is done deliberately to both create unity or to exclude someone from a conversation. It is seen as a sign of solidarity within a group, and it is also assumed that all speakers in a conversation must be bilingual in order code switching occurs. Code switching is used most often when a word doesn't come. The data can be seen below.

Teacher: Is there any truth about advertising?

Student: Truth, kebenaran.

Advertising makes people happy first.

Code switching used to express or to decelerate solidarity. In data (21) can be seen on the words "Truth, kebenaran." The translated words in data (21) deliberately created the unity between speaker and her friends. It was the unifying understanding among them.

\section{Respect the listener}

As a human being the students give the reason when they switch the code also for respect the listener. For example when they are in discussion time they might switch the code to respect the listener. Sometimes they switch the code into Bahasa. It is because the teacher knows there is student who does not have vocabulary as much as she had. The reason is to respect each other as listener. The data can be seen below.

Teacher: Why is it necessary to advertise? Y a kenapa to harus ada iklan? Because there may the profit we don't know.

On the data above code switching used to respect the listener. It has function as tolerance. In data (22) the teacher translated the words she said, it appears in sentence "Why is it necessary to advertise? Ya kenapa to harus ada iklan?" She translated it because she tolerance to her students who may not understand about her explanation.

\section{Being more informative}

When the teacher or student in the classroom, they using bahasa to discuss or sharing about the material with others. It was their way to be an informative human. In teacher' and student' opinion by using English language limit them to discuss with other, so they switch into Bahasa. Meanwhile, when they switch the code into bahasa, they will be more informative to the other. The data can be seen below.

Teacher: Ya jadi kaki saya terluka itu mengekpresikannya seperti

itu. I hurt my foot, I hurt my hand.

Student: Yes miss.

Teacher: Sama saja itu ekpresi juga.

On the (23) code switching used by teacher for being more informative to her students. It has function to emphasize the important notion. In the data, the teacher mentioned important notion in English language. In data (23) can be seen on the words "Ya jadi kaki saya terluka itu mengekpresikannya seperti itu. I hurt my foot, I hurt my hand." She translate it because as her explanation to her students who may not understand about it

The table of aims, functions, and the reasons of code switching were found from the English teacher and students' utterance presented in the appendices.

\section{CONCLUSION}

Regarding to those findings, some conclusions can be drawn as follows:

The English teacher used all of the form of code switching. Meanwhile, her students did not use all form of code switching. They only used code switching in word and phrase form.

The English teacher and her students applied all kinds of code switching in their utterance, except permanent code switching.

The English teacher' aims used code 
switching was to compensating for language limitation, to explain the material, and as strategy in teaching learning process.

Both teacher and student state that code switching has many functions for them. It will be used as clarification about student understanding, to emphasize the important notion, to repeat the difficult word, to translate the material, checking for understanding, as a tool for communication, developing vocabulary, and tolerance.

Code switching occurs because some factors. The factors found are to fulfill a need, to express or decelerate solidarity, respect the listener, and be more informative.

\section{REFERENCE}

Ahmad, B. H. (2009). Teachers' code-switching in classroom instructions for low English proficient learners. CCSE, 2(2), 49-55. Retrieved from https://doi.org/10.5539/ elt.v2n2p49

Alwasilah, C. (1985). Sosiologi bahasa. Bandung: CV Angkasa.

Chaer, A., \& Agustina, L. (2010). Sosiolinguistik perkenalan awal. Jakarta: Rineka Cipta.

Cook, V. (1991). Second language learning and language teaching. Melbourne: Edward Arnold/ Hodder Headline Group.

Dente, R., Tibayan, E., Tan, D. M., Manalaysay, L., Garcia, M., \& Cartel, J. (2016). Code switching and its implications for esl learning. International Journal of Social Science and Humanities Research, 4(1), 241 -248. Retrieved from http:// researchpublish.com

Fachriah, E. (n.d.). The function of code switching in an english language classroom. Studies in English Language and Education, 4(2), 148-
156. Retrieved

from

https://

pdfs.semanticscholar.org/5d14/808799bd373 e6a66cbe37d6797c451592617.pdf

Hornby, A. S. (1995). Oxford advanced learner's dictionary. Oxford: Oxford University Press.

Jingxia, L. (2010). Teachers' code-switching to the L1 in efl classroom. The Open Applied Linguistics Journal, 3, 10-23. Retrieved from doi.org/10.2174/1874913501003010010

Modupeola, O. R. (2013). Code-switching as a teaching strategy: Implication for English language teaching and learning in a multilingual society. IOSR Journal of Humanities and Social Science, 14(3), 9294. Retrieved from http://iosrjournals.org

Moleong, L. J. (2007). Metodologi penelitian kualitatif. Bandung: PT Remaja Rosdakarya.

Nababan, P. W. J. (1984). Sosiolinguistik suatu pengantar. Jakarta: PT. Gramedia.

Obaidullah, M. (2016). Code switching in efl classrooms: A Bangladeshi Perspective. Theory and Practice in Language Studies, 6 (5), 924-934. Retrieved from http:// dx.doi.org/10.17507/tpls.0605.03

Oxford, R. (1990). Language learning strategies: What every teacher should know. New York: Newbury House Publishers.

Poedjosoedarmo, S. (1978). Kode dan alih kode. Yogyakarta: Balai Penelitian Bahasa.

Sudaryanto. (1993). Metode dan aneka teknik analisis bahasa: Pengantar penelitian wahana kebudayaan secara linguistis. Yogyakarta: Duta Wacana University Press.

Wardaugh, R. (2006). Introduction to sociolinguistics (5thed). United Kingdom: Blackwell.

\section{APPENDICES}

Table 1

The Forms of Code Switching and the Kinds of Code Switching in Teacher and Students Utterances

\begin{tabular}{cccccccc}
\hline \multirow{2}{*}{ No } & $\begin{array}{c}\text { Forms of code } \\
\text { switching }\end{array}$ & I.CS & E.CS & T.CS & P.CS & S.CS & M.CS \\
\hline 1. & Words form & 16 & 83 & 99 & - & 98 & 1 \\
2. & Phrases form & 3 & 72 & 75 & - & 74 & 1 \\
3. & Sentences form & - & 93 & 93 & - & 93 & - \\
& Total & 19 & 248 & 267 & 0 & 265 & 2 \\
& & $\mathbf{2 6 7}$ & & $\mathbf{2 6 7}$ & & $\mathbf{2 6 7}$ & \\
\hline
\end{tabular}

* I.CS: Intern code switching, E.CS: Extern code switching, T.CS: Temporary code switching, P.CS: Permanent code switching, S.CS: Situational code switching, M.CS: Metaphorical code switching. 
Table 2

The Aims, the Functions and the reasons of Code Switching in Teacher and Students Utterances

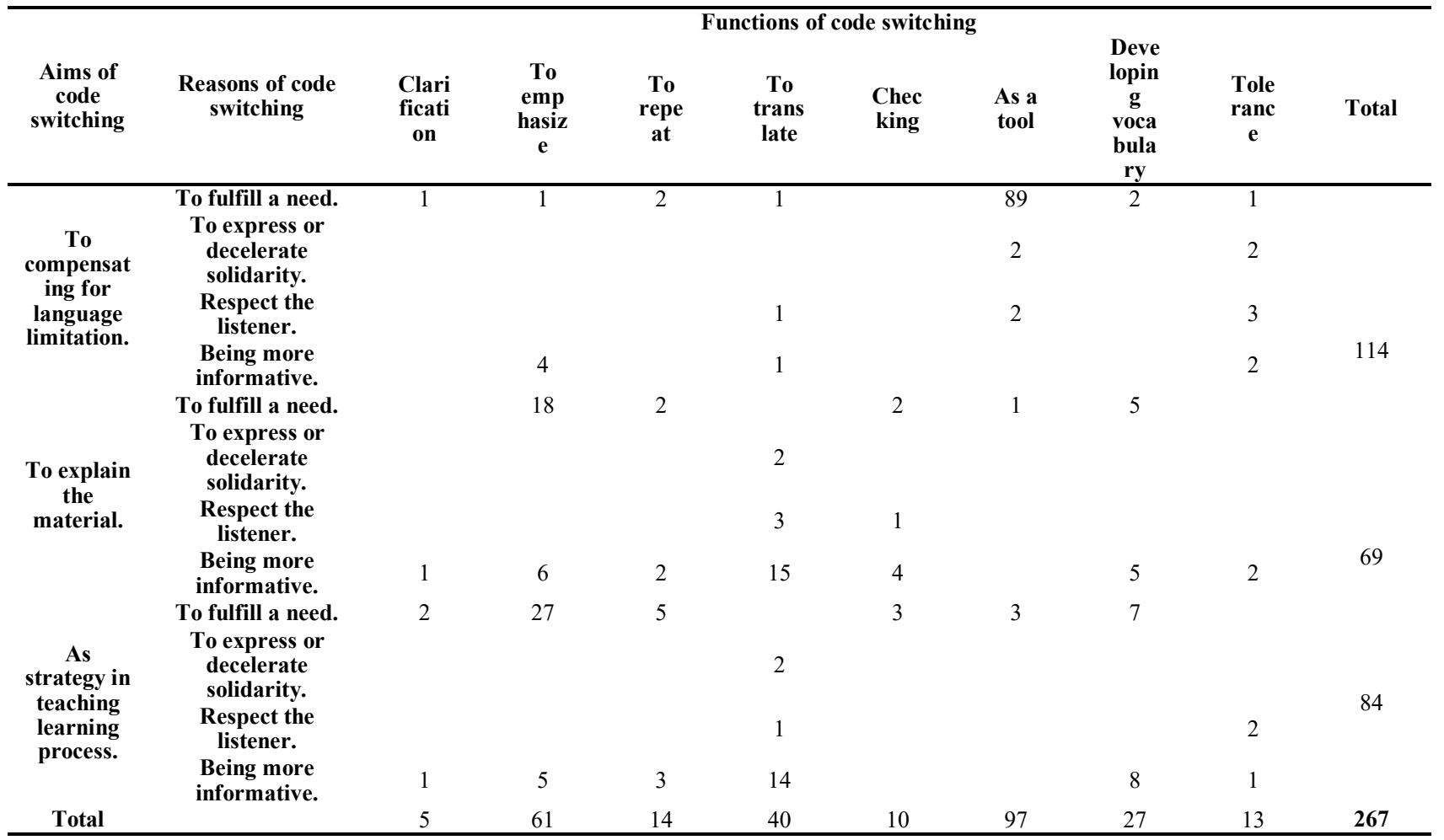

